\title{
URGENSI PENYUSUNAN MODEL BIMBINGAN KESEHATAN MENTAL (MENTAL HYGIENE) SELAMA MENUNGGU EKSEKUSI MATI
}

\author{
Amir Hasan Ramli dan Wiwik Utami \\ Universitas Wisnuwardhana Malang \\ Email:wiwik_utamimh@yahoo.co.id
}

\begin{abstract}
Abstraks
Penelitian ini bertujuan mendiskripsikan urgensi penyusunan model pembimbingan kesehatan mental terpidana mati. Penelitian ini merupakan penelitian hukum-empiris dengan pendekatan yuridis-psikologis. Berdasarkan hasil penelitian, materi dan metode pembimbingan kesehatan mental terpidana mati dilakukan berdasarkan interpretasi masing-masing petugas pemasyarakatan, sepanjang tidak melanggar ketentuan hukum yang berlaku. Hal ini semata-mata dilakukan agar terpidana mati tidak melakukan perbuatan yang melanggar hukum di LAPAS/RUTAN, dan agar lebih siap dalam menghadapi eksekusi mati. Pembimbing berasal dari dalam maupun luar LAPAS. Prosesnya diintegrasikan melalui kegiatan pembinaan bidang keagamaan dengan metode caramah secara massal dan konsultasi individual. Konseling individual merupakan langkah positif untuk membimbing terpidana mati sesuai dengan kebutuhannya. Sayangnya, pembimbingan tersebut belum didasarkan pada hasil pemeriksanaan psikologis, prosesnya juga belum menggunakan prinsip-prinsip konseling sehingga hasilnya belum optimal. Jika pedoman tersebut ada, petugas pemasyarakatan dapat menyusun langkah-langkah pembimbingan secara sah, efisien dan efektif dalam bimbingan dan konseling, sehingga terpidana mati siap dieksekusi.

This research aims at describing the urgence of designing model of sentenced-death prisoner health mental supervision. This research is empiric-law research with psychologicaljuridical approaches. Based on research result, the supervision is conducted based on the interpretation of each officers as long as it does not violate the rule. The aim of this sort of supervision is that the sentenced-death prisoner does not violate the rule and prepare for the death sentence. Supervisors may come from inside or outside the prison. The process is integrated through religious supervision activity with massive sermon and individual consultation. Individual counceling is a positive step to supervise sentenced-death prisoners based on their needs. Unfortunately, the supervision has been based on psychological test, the process has not implement counceling principles that the result can be optimal. If the prison has the guidence, the officers can make legitimate, effective and effficient supervison steps in supervising and counceling in order the prisoners are ready to be executed.
\end{abstract}

Kata-Kata Kunci: bimbingan mental, kesehatan mental, terpidana mati

Penjatuhan pidana merupakan alternatif terakhir dalam kebijakan hukum pidana. Pidana dan pemidanaan mempunyai dampak luas bagi masyarakat, korban, dan pelaku kejahatan, dan keberadaannya selalu dibutuhkan. ${ }^{1}$ Berdasarkan Pasal 10 KUHP,

\footnotetext{
${ }^{1}$ Masruchin Ruba'i, Pidana dan Pemidanaan. (Malang: IKIP Malang, 1994), h. 2.
} 
salah satu jenis pidana pokok di Indonesia adalah pidana mati (the death penalty). Pidana mati dijatuhkan kepada terdakwa yang diancam dengan pidana mati, dengan cara ditembak sampai mati (UU Nomer 2/ PNPS/1964 tentang Tata Cara Pelaksanaan Pidana Mati). Meskipun keberadaan pidana mati selalu kontroversial, ${ }^{2}$ Indonesia tetap memberlakukan pidana mati secara selektif.

Pada tahun 2009, jumlah terpidana mati di Indonesia yang menunggu eksekusi mati sebanyak 109 orang, ${ }^{3}$ karena pemerintah ragu-ragu, ${ }^{4}$ dan hukum pidana Indonesia belum mengatur tentang lama maksimal masa tunggu eksekusi mati. Banyak terpidana yang menunggu eksekusi mati selama berpuluh-puluh tahun di LAPAS, misalnya Bahar bin Matar tinggal selama 38 tahun, Suryadi selama 17 tahun, Thun Tuck Yin selama 13 tahun, ${ }^{5}$ Swabuana selama 16 tahun. ${ }^{6}$ Selama menunggu dan menjelang eksekusi mati, terpidana ditahan di LAPAS/ RUTAN, dan perlu dibina secara khusus agar mentalnya sehat dalam menghadapi eksekusi mati. Mentalitas narapidana yang sehat berpengaruh positif pada perilaku narapidana di LAPAS. ${ }^{7}$

Sampai saat ini belum ada pedoman atau standarisasi khusus tentang bimbingan kesehatan mental (Mental Hygiene) terpidana mati. Petugas pemasyarakatan hanya melakukan bimbingan kesehatan mental sekedarnya tanpa ada arah dan pedoman yang memadai. Jika pedoman tidak ada dan petugas gagal membina terpidana mati, maka terbuka peluang bagi negara untuk "digugat" oleh pihak lain, terutama kaum abolisionis yang selalu menolak pidana

\footnotetext{
${ }^{2}$ J.E. Sahetapy, Suatu Studi Khusus Mengenai Ancaman Pidana Mati terhadap Pembunuhan Berencana. (Jakarta: CV Rajawali, 1982) h. 95

${ }^{3}$ Kejagung Tunggu Fatwa MA, http:www.seputarindonesia.com., diaskses tanggal 21 Agustus 2011.

${ }^{4}$ RUU KUHP Masih Berlakukan Hukuman Mati, hukum online, diaskses tanggal 25 Agustus 2011.

${ }^{5} 52$ Terpidana Mati Tunggu Eksekusi, Radar Semarang, diakses tanggal 2 September 2008.

${ }^{6} 52$ Napi Tunggu Eksekusi Mati, http://www. kapanlagi.com, diaskses tanggal 21 Agustus 2011.

${ }^{7}$ Widodo, Kapita Selekta Hukum Pidana, (Jakarta: Kertagama Publishing, 2007), h. 57.
}

mati (anti pidana mati), karena dianggap melanggar hak asasi manusia. Selain itu, terpidana mati selama menunggu ekskekusi mati juga akan merasa bebas melakukan apasaja di LAPAS karena tidak mungkin akan dijatuhi pidana lagi. Berdasarkan hasil identifikasi kasus di LAPAS, ternyata banyak kejahatan yang dilakukan oleh terpidana mati di dalam LAPAS, misalnya Sugik alias Sugianto melakukan pembakaran sel tahanan di RUTAN Medaeng karena stress, bahkan saat ini Sugik mengalami sakit jiwa di LAPAS Porong. Ada terpidana mati yang menjadi penjudi di ruang Tahanan LAPAS Porong. Samuel Iwacheukwu Okoye dan Hansen Antony Nwaosya, membuat kerusuhan di LAPAS Pasir Putih, Pulau Nusakambangan. ${ }^{8}$ Terpidana mati Taroni dan Irwan kabur dari LAPAS Muara Padang, dan akan membunuh seluruh anggota keluarga korban pembunuhan yang tersisa. ${ }^{9}$ Kejadian ini merupakan suatu indikator bahwa petugas LAPAS belum berhasil membina kesehatan mental terpidana mati. Hal ini terjadi karena adanya keterbatasan sumberdaya manusia, sumber dana, dan ketiadaan pedoman pembinaan yang khusus dapat diterapkan pada terpidana mati.

Berpijak pada fakta dan argumentasi di atas, maka perlu segera disusun pedoman pembinaan mental terpidana mati selama menunggu dan menjelang eksekusi mati yang didasari oleh argumentasi hukum yang jelas dan pertimbangan psikologi yang valid berdasarkan teori penologi dan psikologi yang mengarah pada asas individualisasi pembinaan. Tujuan penelitian ini adalah menganalisis urgensi penyusunan model bimbingan praktis yang dapat digunakan sebagai usulan kepada pemerintah untuk menerbitkan pedoman bimbingan kesehatan mental terpidana mati di LAPAS.

\footnotetext{
${ }^{8}$ Terpidana Mati WN Nigeria Diduga Dalangi Kerusuhan, Radar Semarang tanggal 24 Juni 2008

${ }^{9}$ LP Muara Bobol, Tiga Terpidana Mati Kabur, Harian Singgalang, tanggal 18 Oktober 2007
} 


\section{Tinjauan Pustaka}

Secara sosiologis, pidana mati bukan merupakan budaya baru bagi bangsa Indonesia, karena secara historis, sebelum kaum kolonial datang, pidana mati telah lama dijalankan masyarakat Indonesia di berbagai wilayah, misalnya: Aceh, Toraja, Timor, Bali, dan Jawa. Pelaksanaan pidana mati dilakukan dengan cara yang kejam, ${ }^{10}$ sehingga penjatuhannya harus dilakukan secara hemat, cermat, hatihati, manusiawi (humanely), dan pidana hanya dipakai khusus sebagai obat terakhir (ultimum remedium). ${ }^{11}$

Jumlah tindak pidana (delict) yang diancam pidana mati dalam KUHP di Indonesia cukup banyak, yaitu terdiri atas 13 kelompok jenis kejahatan (bab) ${ }^{12}$ misalnya pembunuhan berencana, makar, pencurian dengan kekerasan. ${ }^{13}$ Selain itu ancaman pidana mati juga ada di luar KUHP, misalnya UU tentang Narkotika, Psikotropika, Pemberantasan Korupsi, Pengadilan Hak Asasi Manusia, Pemberantasan Tindak Pidana Terorisme. Jumlah terpidana mati di Indonesia akan terus bertambah. ${ }^{14}$ Berdasarkantinjauan psikologis, secara umum, tidak ada perbedaan yang mencolok antara karakteristik terpidana mati dan bukan terpidana mati. Tetapi jika dilihat dari temperamen dan reaksinya terhadap putusan pengadilan ada perbedaan. Hal ini dikemukakan oleh Ethika Nugrahini, bahwa ada karakteristik khusus yang berkaitan dengan sikap terpidana mati dalam beradaptasi untuk menghadapi eksekusi mati (dalam istilah psikologi disebut strategi koping). ${ }^{15}$

Sistem pembinaan narapidana di Indonesia didasarkan pada Undang-Undang No. 12

\footnotetext{
${ }^{10}$ J.E. Sahetapy, opcit, 1982, h. 243-244

${ }^{11}$ Barda Nawawi Arief. 1994. Kebijakan Legislatif: dalam Penanggulangan Kejahatan dengan Hukum Pidana, (Semarang: Badan Penerbitan Universitas Diponegoro, 1994), h.221

${ }^{12}$ Ibid.

${ }^{13}$ Andi Hamzah dan Siti Rahayu. Suatu Tinjauan Ringkas Sistem Pemidanaan di Indonesia, (Jakarta: Akademi Presindo, 1984), h. 26

${ }^{14} \mathrm{Ibid}$.

${ }^{15}$ Ethika Nugrahini, Strategi Koping Menghadapi Pidana Mati pada Terpidana Mati, (Surakarta: Universitas Muhammadiyah Surakarta, 2007).
}

Tahun 1995 tentang Pemasyarakatan, dan Peraturan Pemerintah No. 31 Tahun 1999. Namun, di dalamnya tidak diatur secara khusus tentang bimbingan kesehatan mental terpidana mati. Terpidana mati adalah terpidana yang tidak akan dikembalikan lagi ke masyarakat, melainkan akan di-eksekusi mati sehingga mereka perlu disiapkan untuk mati. Ironi, sampai saat ini belum ada pedoman khusus tentang bagaimana teknik bimbingan kesehatan mental terpidana mati.

Hukum pidana Indonesia tidak mengatur tujuan pemidanaan secara tegas. Tujuan pemidanaan hanya dapat diketahui dari ajaran/ doktrin ahli hukum pidana. Dalam sejarah perkembangan hukum pidana dapat diungkapkan adanya 3 macam teori yang mengemukakan tujuan pemidanaan, yaitu teori absolut (vergelding theorien), teori relatif (doel theorien), dan teori gabungan (vernengings theorien). ${ }^{16}$ Teori tersebut mengkaji tentang alasan pembenar penjatuhan pidana. ${ }^{17}$ Indonesia mengikuti pergeseran paradigma pemidanaan (Sentencing Paradigm), dari paradigma lama yang mendasarkan pada asas legalitas sehingga menimbulkan pertanggungjawaban pidana yang berorientasi pada perbuatan, ke arah pandangan yang mendasarkan pada asas kulpabilitas sehingga menimbulkanpertanggungjawabanpidanayang diorientasikan pada orang (pelaku tindak pidana), konsepsi pembinaan juga bergeser dari konsep reaksi pemidanaan (punitive reactions) ke arah suatu modifikasi konsep reaksi pembinaan (treatment reactions). ${ }^{18}$ Berdasarkan pandangan tersebut, Widodo berpendapat konsepsi arah pemasyarakatan di Indonesia didasarkan pada teori gabungan, yaitu dalam pemidanaan sekaligus memuat unsur penderitaan, pembinaan, dan upaya menertibkan kehidupan masyarakat. Ini tampak jelas dalam pelaksanaan pembinaan

${ }^{16}$ Adami Chazawi, Pelajaran Hukum Pidana (Bagian I), (Malang: Biro Konsultasi dan Bantuan Hukum Fakultas Hukum Universitas Brawijaya, 2001), h. 170.

${ }^{17}$ Made Sadhi Astuti, Pemidanaan Terhadap Anak Sebagai Pelaku Tindak Pidana, (Malang: IKIP Malang, 1997), h. 29.

${ }^{18}$ Bambang Purnomo. Kapita Selekta Hukum Pidana. (Yogyakarta: Liberty, 1984), h. 4. 
nara pidana di Lembaga Pemasyarakatan (LAPAS). Dalam LAPAS, kemerdekaan terpidana dibatasi (deprived of liberty), sehingga merasakan penderitaan.Berdasarkankonsepsi tersebut maka narapidana di LAPAS memperoleh pembinaan dan pendidikan secara manusiawi agar dapat bermasyarakat kembali dan tidak melakukan kejahatan kembali dan dapat hidup wajar sebagaimana anggota masyarakat lainnya. ${ }^{19}$

Hasil penelitian Wilson Simanjuntak mengungkapkan bahwa program pembinaan mental, rohani, dan keterampilan di LAPAS dimaksudkan untuk mempersiapkan narapidana agar setelah dibina dan dibimbing di LAPAS dapat hidup sebagai anggota masyarakat yang baik di tengah masyarakat..$^{20}$ Pola pembinaan dengan program-program yang menyangkut aspek mentalitas, kecerdasan, keterampilan kerja dan religiusitas menjadi sebuah tuntutan yang penting. lndikator standar keberhasilan pembinaan diLAPASKelas ICipinangJakarta belum ada, dan ternyata angka residivis di LAPAS tersebut yang cukup tinggi. ${ }^{21}$

Meskipun saat ini ada pembinaan kesehatan mental terhadap terpidana mati, tetapi hanya dilakukan oleh rohaniwan menjelang eksekusi pidana mati, yaitu paling lama 3 hari sebelum eksekusi di ruang isolasi. Pembinaan yang relatif singkat tersebut masih kurang layak bagi terpidana mati dan keluarganya. Kalau ada pembinaan selama menunggu eksekusi mati, hanya dilakukan bersamaan dengan pembinaan bidang keagamaan. Hal ini akan merugikan beberapa pihak karena terpidana mati belum tentu mempunyai kesehatan mental yang mantap.

Kesehatan mental adalah terhindarnya

${ }^{19}$ Widodo, Pemberantasan Cybercrime: Teori dan Aplikasi Kebijakan Non-Penal (Perbandingan antara Pelaksanaan di Indonesia, di Luar Negeri, dengan Kebijakan Internasional), (Jakarta: Kertagama Publishing, 2007), h. 46

${ }^{20}$ Wilson Simanjuntak, Upaya Mengurangi Stigma Masyarakat pada Narapidana, Tesis, Universitas Indonesia, 2003, h. 24.

${ }^{21}$ Sahat F. Aritonang, Sistem Pemasyarakatan dan Pola Pembinaan Mental Narapidana Kriminal dalam Lembaga Pemasyarakatan (Studi Kasus Lembaga Pemasyarakatan Cipinang), Tesis, Universitas Indonesia, 2005, h. 56. orang dari gejala-gejala gangguan jiwa (neurose) dan dari gejala-gejala penyakit jiwa (psychose), dan mampu menyesuaikan diri dengan diri sendiri, dengan orang lain dan masyarakat serta lingkungan di mana ia hidup sehingga dapat mengembangkan dan memanfaatkan segala potensi, bakat dan pembawaan yang ada semaksimal mungkin, sehingga membawa kepada kebahagiaan diri dan orang lain dan keharmonisan yang sungguh-sungguhantarafungsi-fungsijiwa. ${ }^{22}$ Prinsip-prinsip kesehatan mental tersebut mencakup prinsip yang didasarkan atas sifat manusia, hubungan manusia dengan lingkungannya, dan hubungan manusia dengan Tuhan. ${ }^{23}$ Secara teoretik, pribadi yang normal yaitu yang bermental sehat adalah pribadi yang menampilkan tingkah laku yang adekuat dan bisa diterima masyarakat pada umumnya, sikap hidupnya sesuai norma dan pola kelompok masyarakat, sehingga ada relasi interpersonal dan intersosial yang memuaskan. $^{24}$ Secara yuridis ditentukan bahwa suatu keadaan sehat secara fisik, mental, dan sosial memungkinkan setiap manusia untuk hidup produktif baik secara sosial maupun ekonomis. ${ }^{25}$ Berdasarkan pada konsepsi tersebut maka terpidana yang dijatuhi pidana mati yang mentalnya sehat akan cenderung bertingkah laku manusiawi, karena pada dasarnya stabilitas mental dapat meningkatkan kemampuan beradaptasi, dan kapasitas mengubah situasi dan kepribadiannya.Untukmenyehatkanmental, diperlukan langkah-langkah psikologis yang tepat di LAPAS atau RUTAN, dan tidak bertentangan dengan hukum pidana.

Berdasarkan pendapat, ketentuan hukum, dan hasil penelitian di atas dapat dipahami bahwa arah pembinaan mental narapidana di Indonesia adalah melakukan upaya pembimbingan kesehatan mental dan

${ }^{22}$ Zakiah Daradjat, Kesehatan Mental, (Jakarta: Gunung Agung, 1985), h. 10-14

${ }^{23}$ Moeljono Notosoedirjo, dan Latipun, Kesehatan Mental dan Konsep-Konsep Penerapan (Malamg: UMM Press, 2000), h. 129-30

${ }^{24}$ Kartini Kartono, Gangguan-Gangguan Psikis (Bandung: Sinar Baru, 1989), h. 43

${ }^{25}$ Undang-Undang No.23 Tahun 1992 
kerohanian secara manusiawi agar bertobat atas segala kesalahannya dan menyiapkan seoptimal mungkin eksekusi mati. Mentalitas narapidana yang sehat berpengaruh pada pembentukan tingkah laku yang positif dalam LAPAS.

Untuk mencapai tujuan pembinaan terpidana mati, maka pembinaan kesehatan mental terpidana mati dilakukan dengan model pendidikan orang dewasa (andragogy), karena semuanya berusian diatas 18 tahun. Pendidikan ini mengutamakan pendidikan yang manusiawi. Knowles mengklasifikasi teknik pembelajaran dalam mencapai tujuan belajar berdasarkan tipe kegiatan belajar orang dewasa, adalah sikap, pengetahuan dan keterampilan. ${ }^{26}$ Prinsip pembelajaran yang partisipatif pada orang dewasa adalah (a) Kebutuhan belajar didasarkan pada kebutuhan belajar (learning needs based); (b) kegiatan pembelajaran berorientasi pada tujuan kegiatan pembelajaran (learning goals and objectives oriented), (c) pembelajaran berpusat pada peserta didik (participant centered); (d) kegiatan pembelajaran berpijak dari pengalaman belajar (experiential learning). ${ }^{27}$

Berpijak pada teori pembelajaran orang dewasa tersebut dapat dipahami bahwa dalam membina terpidana mati, eksisitensi terpidana mati menduduki posisi yang paling strategis. Petugas Pemasyarakatan di LAPAS hanya berfungsi sebagai fasilitator dalam pembinaan, tetapi kadangkala juga berfungsi sebagai pemecah masalah. Unsur konsep diri terpidana mati, peranan pengalaman, kesiapan belajar, dan orientasi belajar menjadi unsur utama dalam pembelajaran, Karena itu, penyusunan model bimbingan kesehatan mental terpidana mati dalam LAPAS tidak dapat lepas dari paradigma pembelajaran orang dewasa. Metode pembinaannya juga harus berpijak pada

\footnotetext{
${ }^{26}$ Malcolm Knowles. The Modern Practice of Adult Education, Andragogy Versus Pedagogy. (New York: Assosiation Press, 1977), h. 34.

${ }^{27}$ H.D Sudjana, Strategi Pembelajaran dalam Pendidikan Luar Sekolah. (Bandung: Falah Production, , 2000), h. 172-174
}

karakteristik pembelajaran orang dewasa. Pengembangan model bimbingan kesehatan mental ini akan memberikan dampak positif, baik terhadap petugas pemasyarakatan, narapidana, maupun lingkungan lembaga pemasyarakatan; dan menunjukkan adanya jaminan tentang kesinambungan (sustainability) model yang dikembangkan. Karena itu penciptaan iklim pembelajaran yang kondusif, pelibatan warga belajar dalam pembelajaran (belajar partisipatif), proses pendidikan yang prospektif di lembaga pemasyarakatan agar dapat membawa perubahan mental. ${ }^{28}$

Pembimbingan kesehatan mental terpidana mati selama menunggu dan menjelang eksekusi mati di LAPAS atau RUTAN dengan mengunakan metode andragogi tersebut sesuai dengan pemikiran aliran modern dalam hukum pidana. Aliran modern (aliran positif) dalam hukum pidana melahirkan konsepsi tentang individualisasi pemidanaan. Lombrosso menyimpulkan bahwa penjahat yang memiliki ciri-ciri khusus sebagai manusia jahat tersebut hanya 35\% dari seluruh penjahat, ${ }^{29}$ sehingga setiap penjahat mungkin dibina agar lebih baik.

Berpijak pada aliran positivisme, dan hasil penelitian, serta karakteristik terpidana mati maka bimbingan kesehatan mental terpidana mati masih mungkin dilakukan dengan cara melakukan perlakuan (treatment) klinis dan modifikasi perilaku secara psikologis agar tingkah lakunya menjadi lebih baik dalam menghadapi eksekusi mati. Hal ini didasarkan pemikiran bahwa melalui perawatan medis, psikologis, terpidana mati dapat diubah perilakuknya melalui teknik pendidikan orang dewasa (andragogy) dan bimbingan. Asumsi lainnya, dalam prinsip pemidanaan modern, bahwa narapidana sebenarnya adalah "orang sakit" yang me-

${ }^{28}$ Mulyasa, Pengembangan Model Andragogi Bagi Pembinaan Narapidana Perempuan di Lembaga Pemasyarakatan (Studi Terfokus pada Pendidikan Keagamaan (Islam) di Lembaga Pemasyarakatan Kelas IIA Bandung), Tesis, Program Pascasarjana Universitas Pendidikan Indonesia (UPI), Bandung, 2005.

${ }^{29}$ Soerjono Soekanto dan Pudji Santoso, Kamus Kriminologi, (Jakarta: Rajawali, 1988), h. 26-27. 
merlukan pengobatan, salah satunya bimbingan kesehatan mental. ${ }^{30}$

Secara yuridis, karena sifat "legisme" dari penegak hukum dan pembimbing mental dan kerohanian di seluruh Indonesia sangat kuat, maka sangat cocok jika ada pedoman khusus tentang pembimbingan terpidana mati di LAPAS atau RUTAN. Berdasarkan pedoman yang dutangkan dalam produk hukum, maka pembimbing kesehatan mental terpidana mati (yaitu petugas pemasyarakatan di LAPAS atau pihak lain yang diajak kerjasama dengan LAPAS), akan meyakini bahwa apa yang akan dilakukan bersifat legal (sah).

\section{Metode Penelitian}

Penelitian yang dilakukan di LAPAS Kelas I Porong Sidoarjo, LAPAS Kelas I Lowokwaru Malang, dan RUTAN Medaeng Surabaya, tergolong dalam penelitian hukum-empiris, dengan pendekatan yuridispsikologis. Untuk mencapai tujuan, peneliti melakukan studi dokumentasi (documentary research) dan studi lapangan (field research). Studi dokumen dilakukan dengan melakukan kompilasi dan analisis terhadap peraturan perundang-undangan yang terkait dengan pemidanaan terpidana mati dan pembimbingan kesehatan mental. Sedangkan studi lapangan dilakukan di lokasi penelitian. Data data primer dan data sekunder dibutuhkan untuk bahan analisis data. Data primer diperoleh dari Petugas Pemasyarakatan, psikolog, ahli hukum, penolog, rohaniwan, dan ahli pendidikan. Data sekunder diperoleh dari bahan-bahan pustaka. ${ }^{31}$

Pengumpulan data dilakukan dengan menggunakan kuesioner, wawancara, dan observasi. Dalam melakukan analisis data, peneliti melakukan pengeditan (editing), pengkodean (coding), pengkategorian untuk klasifikasi, menghitung frekuensi,

\footnotetext{
${ }^{30}$ Barda Nawawi Arif, 1996, op.cit.

${ }^{31}$ Soerjono Soekanto dan Sri Mamudji. Penelitian Hukum Normatif: Suatu Tinjauan Singkat. (Jakarta: Rajawali Press, 1995), h. 12-13.
}

tabulasi melalui teknik tabel silang, analisis data. ${ }^{32}$ Sedangkan analisis data sekunder yang diperoleh melalui studi dokumentasi, peneliti melakukan langkah-langkah analisis sebagaimana dikemukakan oleh Sri Mamudji, yaitu menggunakan sistem SQ-3 $\mathrm{R}$, yakni survey, question, read, recite/recall, review. Analisis ini digunakan dalam rangka memudahkan membuat suatu tesis, antitesis, dan sintesis antara pendapat ahli atau ketentuan-ketentuanhukumdalamperaturan perundang-undangan. Data lengkap tersebut kemudian dianalisis secara kualitatif cara menguraikan secara deskriptif-analitis dan preskriptif. Pendekatan fenomenologis juga digunakan untuk menganalisis data. Dalam melakukan analisis kualitatif yang bersifat deskriptif dan preskriptif ini, analisis bertitik tolak pada analisis yuridis-sistematis yang dilengkapi dengan analisis empiris serta analisiskomparatif, ${ }^{33}$ sehingga akandiperoleh urgensi penyusunan model pembimbingan kesehatan mental terpidana mati yang prospektif baik selama menunggu eksekusi mati, maupun menjelang eksekusi mati untuk pedoman Petugas Pemasyarakatan

\section{Hasil Penelitian dan Pembahasan}

Secara yuridis, fenomena pembimbingan kesehatan mental terpidana mati benar-benar membingungkan pihak terpidana mati dan petugas pemasyarakatan. Hal ini disebabkan oleh belum adanya petunjuk teknis tentang perawatan kesehatan mental tahanan yang dijatuhi pidana mati, serta kesiapan LAPAS atau RUTAN untuk membina kesehatan mental terpidana mati.

Berdasarkan istilah selama yang digunakan, istilah terpidana mati juga mengandung kelemahan. Istilah terpidana selalu menunjukpadaseseorangyangsudahdijatuhi pidana oleh pengadilan dan putusannya sudah mempunyai kekuatan hukum tetap, mislanya terpidana penjara. Namun, khusus istilah terpidana mati, mestinya hanya akan

\footnotetext{
${ }^{32}$ Koenjtaraningrat, op. cit. 1981, h . 330-331.

${ }^{33}$ Sunaryati Hartono, Penelitian Hukum Menjelang Abad XXI, (Bandung: Alumni, 1984), h. 38.
} 
dapatdigunakansetelahterpidana dieksekusi mati. Jika terpidana masih menunggu dan menjelang eksekusi mati, sebenarnya lebih tepat disebut " tahanan yang dijatuhi vonis pidana mati." Meskipun demikian, jika istilah "terpidana mati" tersebut disambung dengan kata-kata berikutnya, "selama menunggu dan menjelang eksekusi mati", maka tidak ada persoalan yuridis. Karena itu, pemaknaan istilah "terpidana mati" dalam penelitian ini harus dijadikan satu dengan kata-kata selanjutnya, sehingga menjadi sebuah frasa. Namun demikian, perbedaan penafsiran tersebut tidak menghalangi proses pembinaan terpidana mati.

TerpidanamatiyangdibinadiLAPASKelas I Surabaya di Porong (selanjutnya disingkat LAPAS Porong) adalah: Aris Setiawan, Suud Rusli, Nurhasan Yogi Mahendra, Sugianto alias Sugik, Markus Pata Sambo, dan Hangky Gunawan. ${ }^{34}$ Sedangkan terpidana mati yang dibina di LAPAS Kelas I Lowokwaru Malang (selanjutnya disingkat LAPAS Lowokwaru) hanya ada 1 orang, yaitu Marthinus Pata (Ayah Markus Pata Sambo). ${ }^{35}$ Terpidana mati tersebut ditempatkan dalam Blok khusus. Mereka boleh dikunjungi keluarga atau kerabatnya, tetapi selalu dilakukan pengawasan yang sangat ketat dari Petugas LAPAS. Pengawasan terpidana mati selama dalam sel tahanan juga selalu diperketat, agar tidak melakukan perbuatan yang melanggar hukum, misalnya melakukan tindak pidana di dalam LAPAS, bunuh diri, membuat kerusuhan, atau melarikan diri. Namun, keketatan dalam pengawasan ini dilakukan secara manusiawi. ${ }^{36} \mathrm{Hal}$ ini juga sama seperti yang dilakukan di LAPAS lowokwaru, ${ }^{37}$ agar tidak seperti kejadian pada tahun 2010, yaitu ada enam terpidana mati berhasil melarikan

\footnotetext{
${ }^{34}$ Data Sekunder di Bagian Registrasi LAPAS Porong, Juli 2011.

${ }^{35}$ Wawancara dengan Udin, Pegawai LAPAS Lowokwaru Malang.

${ }^{36}$ Wawancara dengan Bp. Bambang, Kepala Kesatuan Pengamanan Lembaga Pemasyarakatan (KPLP) LAPAS Porong, di Lapangan Olah Raga, tanggal 14 Agustus 2011.

${ }^{37}$ Wawancara dengan Bp. Mulyadi, Kepala Bidang Seksi Pembinaan Narapidana LAPAS Lowokwaru, di Ruang Kerja, tanggal 16 September 2011.
}

diri dari sejumlah LAPAS di Indonesia. ${ }^{38}$

Berdasarkan pengamatan, ${ }^{39}$ secara mental, dari keenam terpidana mati di LAPAS Porong, ternyata Sugianto alias Sugik adalah terpidana mati yang paling tidak sehat mentalnya, karena dia mengalami gangguan jiwa atau bahkan dapat dikategorikan gila. Sedangkan terpidana mati yang paling sehat mentalnya adalah Suud Rusli. Kondisi Sugik sampai saat ini tidak mengalami perubahan berarti. ${ }^{40}$ Pihak LAPAS sudah melakukan upaya penyembuhan, tetapi karena keterbatasan akses dan tenaga ahli, maka juga belum berhasil..$^{41}$ Kalau di LAPAS Lowokwaru, kondisi mental terpidana mati cukup stabil. Indikatornya, dia tidak menunjukkan tingkah laku yang aneh, dan dapat bersosialisasi dengan nerapidana lain secara wajar. Hanya sesekali, dipanggil oleh Psikolog LAPAS untuk diberi pembimbingan mental agar tetap tabah dalam menghadapi cobaan hidup. ${ }^{42}$

Terpidana mati hanya akan diberikan pembinaan kepribadian, kerohanian, dan keagamaan. Program pembinaan kepribadian diarahkan pada pembinaan mental dan watak agar bertanggung jawab pada diri sendiri, keluarga dan masyarakat Pembinaan kepribadian: ketaqwaan kepada Tuhan Yang Maha Esa; kesadaran berbangsa dan bernegara; intelektual; sikap dan perilaku; kesehatan jasmani dan rohani; dan kesadaran hukum. ${ }^{43}$ Dalam proses pembinaan, semua pembimbing di LAPAS mempunyai peranan penting. Meskipun demikian, pegawai dalam bidang Pembinaan, Kegiatan Kerja, dan

\footnotetext{
${ }^{38}$ Enam Terpidana Mati Melarikan Diri, Koran SINDO, tanggal 16 November 2010.

${ }^{39}$ Observasi di Sel Tahanan Lapas Porong, tanggal 12 Agustus 2011.

${ }^{40}$ Wawancara dengan Bp. Eddy Turyono, Kepala Bidang Pembinaan Narapidana, LAPAS Porong, di Ruang Kerja, tanggal 12 Agustus 2011.

${ }^{41}$ Wawancara dengan Bp. Eddy Turyono, Kepala Bidang Pembinaan Narapidana, LAPAS Porong, di Ruang Kerja, tanggal 12 Agustus 2011.

${ }^{42}$ Wawancara dengan Bp. Mulyadi, Kepala Bidang Seksi Pembinaan Narapidana LAPAS Lowokwaru, di Ruang Kerja, tanggal 16 September 2011.

${ }^{43}$ Wawancara dengan Bp. Eddy Turyono, Kepala Bidang Pembinaan Narapidana, LAPAS Porong, di Ruang Kerja, tanggal 14 Agustus 2011
} 
KPLP mempunyai peraran yang lebih dominan, terutama dalam pembinaan tingkah laku terpidana mati. ${ }^{44}$ Pembimbing pemasyarakatan mempunyai peranan yang sangat menentukan dalam rangka memulihkan rasa pecaya diri dan menyadari tentang kesalahan yang telah dilakukan, sehingga mentalitas terpidana mati lebih baik. ${ }^{45}$

Selama ini, pembimbingan kesehatan mental terpidana mati dilaksanakan bersamasama dengan narapidana dan tahanan lainnya. ${ }^{46}$ Hal ini dilakukan karena selama ini belum ada pedoman khusus tentang pembimbingan kesehatan mental terpidana mati. ${ }^{47}$ Karena itu, pembinaan mental yang dilakukan dikategorikan dalam Pembinaan Kepribadian. Hal ini dapat dipahami karena mayoritas Pegawai LAPAS berpendidikan terakhir lulusan SMA dan yang sederajat. Di LAPAS Lowokwaru hanya ada 2 orang Psikolog (di Bagian Pembinaan Narapidana dan di Bagian Kepegawaian). Sedangkan jumlah pegawai yang ikut membina dalam bidang keagamaan jumlahnya 5 orang. ${ }^{48}$ Di LAPAS Porong hanya ada 1 orang psikolog, namun ditempatkan paga Bagian Kunjungan. ${ }^{4}$ Pembimbing kesehatan mental lain berasal dari dalam dan luar LAPAS. Sedangkan sarana dan prasarana pembimbingan kesehatan mental antara LAPAS Porong dengan Lowokwaru relatif sama, karena keduanya berperingkat sebagai

${ }^{44}$ Wawancara dengan Bp. Eddy Turyono, Kepala Bidang Pembinaan Narapidana, LAPAS Porong, di Ruang Kerja, tanggal 14 Agustus 2011.

${ }^{45}$ Wawancara dengan Bp. Mulyadi, Kepala Bidang Seksi Pembinaan Narapidana LAPAS Lowokwaru, di Ruang Kerja, tanggal 16 September 2011.

${ }^{46}$ Wawancara dengan Bp. Mulyadi, Kepala Bidang Seksi Pembinaan Narapidana LAPAS Lowokwaru, di Ruang Kerja, tanggal 16 September 2011. Wawancara dengan Bp. Eddy Turyono, Kepala Bidang Pembinaan Narapidana, LAPAS Porong, di Ruang Kerja, tanggal 14 Agustus 2011.

${ }^{47}$ Wawancara dengan Bp. Joko, Kepala LAPAS Lowokwaru, dan Mantan Kepala RUTAN Medaeng, di Ruang Kerja, tanggal 21 September 2011.

${ }^{48}$ Wawancara dengan Bp. Mulyadi, Kepala Bidang Seksi Pembinaan Narapidana LAPAS Lowokwaru, di Ruang Kerja, tanggal 16 September 2011.

${ }^{49}$ Wawancara dengan Bp. Eddy Turyono, Kepala Bidang Pembinaan Narapidana, LAPAS Porong, di Ruang Kerja, tanggal 14 Agustus 2011

\section{LAPAS Kelas I. ${ }^{50}$}

Pembinaan kepribadian dilakukan dengan cara pembinaan kesadaran beragama yang diwujudkan dalam bentuk pengajian rutin bagi yang beragama Islam, kebaktian bagi yang beragama Kristen, dan kegiatan keagamaan lain yang disesuaikan dengan kepercayaan narapidana. Kegiatan ini dilaksanakan seminggu sekali dan merupakan suatu kewajiban bagi semua narapidana. Pembinaan ini dilakukan secara berkelompok dan digilir. Selain itu, pembinaan kesadaran berbangsa dan bernegara. Dalam kegiatan ini narapidana dijelaskan tentang hak dan kewajibannya selama didalam lembaga pemasyarakatan. Untuk menindaklanjuti 2 macam kegiatan tersebut, diadakan pendampingan narapidana oleh wali narapidana. Wali narapidana adalah petugas lembaga pemasyarakatan. Dimana suatu wali narapidana bertanggungjawab terhadap beberapa orang narapidana. Pembinaannya dilakukan secara berkelompok. Tugas wali narapidana adalah mengawasi perilaku narapidana, memberikan rekomendasi dan nasihat.

Kepala LAPAS Kelas I Surabaya di Porong, Nur Achmad S., mengungkapkan, secara umum pola pembinaan narapidana di LAPAS ini telah dibagi dalam tiga bidang binaan, yaitu pembinaan pengetahuan umum, pembinaan kerohanian, pembinaan yang sifatnya langsung yaitu berupa keterampilan. ${ }^{51}$ Wakhit Hasim, Program Officer Search for Common Ground, menyatakan bahwa di LAPAS Kelas I Surabaya di Porong dilaksanakan pelatihan manajemen konflik. Pelatihan ini dilaksankaan terhadap 25 (teroris, koruptor dan mantan pengguna narkoba) yang berkategori risiko tinggi. Hal ini didasarkan pada fakta bahwa mengelola emosi, kemampuan berkomunikasi serta mengelola konflik secara konstruktif merupakan keterampilan yang penting untuk dimiliki narapidana/warga binaan pema-

\footnotetext{
${ }^{50}$ Observasi di LAPAS Porong tanggal 13 Agustus 2011, dan LAPAS Lowokwaru tanggal 16 September

${ }^{51}$ Penghuni LAPAS Porong diberi Pembinaan Kerohanian. Harian Bhirawa. Selasa 11 Mei 2011
} 2011. 
syarakatan. Tujuan pelatihan tersebut adalah agar narapidana mampu mengelola potensi persoalan yang ada di dalam LAPAS. Pelatihan ini juga bertujuan untuk memampukan partisipan (narapidana) dalam manajemen konflik yang berorientasi untuk mengubah penanganan konflik dari pendekatan destruktif menjadi pendekatan konstruktif di LAPAS. Pelatihan ini dipersiapkan dan dilakukan berdasarkan tiga prinsip yaitu pemberdayaan, membuat pilihan-pilihan positif dan memanusikan orang lain. Materi yang diberikan seperti pengelolaan konflik perspektif, kekuatan, kepentingan, komunikasi, budaya, rasa percaya, afirmasi dan kepercayaan diri, negosiasi, mediasi, memprediksi konflik, serta mengelola emosi dan amarah, membangun perdamaian, visi masa depan, life planning di samping berbagai materi lainnya. Hal ini merupakan aspek yang terpenting dalam pengelolaan emosi. ${ }^{52}$

Pembimbingan kesehatan mental dilakukan secara massal dan secara individual. Pembinaan secara massal (termasuk terpidana mati) dilakukan melalui khutbah shalat jumat, ceramah keagamaan di Masjid. Sedangkan secara pribadi akan dilakukan berdasarkan kebutuhan tertentu secara personal. ${ }^{53}$

Berdasarkan uraian di atas dapat dipahami bahwa pembimbingan mental dan kerohanian di dalam Ruang Esolasi di Rutan Medaeng sudah dilakukan, namun belum ada pedoman yang jelas tentang pelaksanaan pembimbingan kesehatan mentalnya. Terpidana mati pada saat menjeleng eksekusi juga mendapatkan bimbingan kesehatan mental, termasuk pengecekan kesehatan fisiknya. Secara teorerik, pembimbingan mental dan kerohanian terpidana mati sangat diperlukan karena tingkah laku akan dikendalikan oleh mentalitas seseorang. Melalui pembimbingan kesehatan mental juga akan terhindardari stress. Melalui pembinaan

${ }^{52}$ Napi Risiko Tinggi Diberi Pelatihan Kendalikan Emosi. http://surabaya.detik.com. 10 Mei 2010

${ }^{53}$ Ribuan Napi Lapas Porong Bertobat, Nusantara. Metrotvnews.com. Rabu, 11 Mei 2011 tersebut, sedikit demi sedikit akan tumbuh rasa penyesalan dan memungkinkan narapidana tidak mengulangi kesalahannya. Pendidikan mental dan kerohanian bertujuan memberikan bekal kecerdasan spritual kepada narapidana. Pendidikan mental dilaksanakan melalui pembinaan di bidang keagamaan dan budi pekerti. Melalui pendidikan mental diharapkan narapidana dapat mengendalikan diri, baik didalam maupun diluar LAPAS. Jika narapidana mampu mengendalikan diri maka akan melakukan tingkah laku yang tidak melanggar hukum. Tingkah laku manusia didasarkan pada sikap. Jika sikap manusia suda diarahkan pada pikiran-pikiran yang bersifat positif, kemudian lingkungan mendukung sikap tersebut, maka memungkinkan besar kemungkinan akan melahirkan tingkah laku nonkriminal. ${ }^{54}$

Berdasarkan keterangan Suwanto proses pembinaan mental narapidana di RUTAN Medaengdilakukandengancaramengadakan kerjasama dengan dokter dan tokoh agama. Sebab, selain petugas RUTAN, hanya mereka yang diperbolehkan mendekati para tahanan. Mereka yang memberikan terapi psikis dan mental spiritual sesuai dengan agama yang diyakini masing-masing narapidana. Pemerintah, khususnya Departemen Agama juga merupakan pihak yang ikut membantu pembinaan mental dan moral keagamaan. Rutan Medaeng selalu berusaha membantu rehabilitasi mental spiritual para narapidana. Dalam rangka pembimbingan kesehatan mental dan penyadaran beragama, RUTAN ini juga bekerjasama dengan Departemen Sosial, Depertemen Pendidikan dan Kebudayaan, IAIN, lembaga-lembaga sosial-keagamaan seperti Yayasan YDSF dan beberapa lembaga keagamaan lainnya. Total ada 9 lembaga keagamaan Islam dan 22 Gereja yang ikut membantu kami. ${ }^{55}$

Pembimbingan binaan mental terpidana

\section{${ }^{54}$ Ibid.}

${ }^{55}$ Petugas Rutanpun Butuh Bimbingan Mental Spiritual, Mimbar Pembangunan Agama (MPA), Edisi Khusus, No. 280 / Muharam / Shafar / Th. 1431 H / Januari 2010 / TH. XXXIX, h. 49. 
mati dilakukan oleh rohaniwan. Pada saat menjeleng eksekusi Astini (terpidana mati kasus mutilasi), semua kagiatan terpidana selama dicatat oleh petugas pemasyarakatan, dan dilaporkan setiap jam kepada Kapala Rutan. Kegiatan yang cicatat adalah semua aktivitas, misalnya shalat, tidur, makan, membacara, berdoa. Terpidana tersebut selalu didampingi oleh seorang petugas pemasyarakatan dalam ruang esolasi, dan jika dibutuhkan selalu ada rohaniwan yang mendampingi dalam ruang esolasi. ${ }^{56} \mathrm{Pi}$ hak LAPAS juga tidak menginginkan jika terpidana mati yang akan dieksekusi kemudian mengamuk dan merusak fasilitas LAPAS. ${ }^{57}$

Di LAPAS Lowokwaru dan Porong, pembimbingan kesehatan mental terpidana mati dilakukan secara massal dan individual. Namun, pembimbing dalam melakukan pembimbingan kesehatan mental tersebut bersifat "menunggu" yaitu menunggu gejala ketidaksehatan mental terpidana mati yang tampak dalam tingkah lakunya. Pembimbingan belum mengarah pada bagaimana pembimbingan secara individual dapat dilaksanakan untuk mengantisipasi agar tidak terjadi gangguan mental. ${ }^{58}$

Berdasarkan paparan di atas dapat dipahami bahwa pembimbingan kesehatan mental sudah diadakan di LAPAS sesuai dengan kebijakan Kepala LAPAS. Karena belum ada pedoman khussu untuk pembimbingan mental terpidana mati selama menunggu eksekusi mati di LAPAS, maka pembinaannya sering disamakan dengan pembimbingan mental dan kerohanian melalui kegiatan keagamaan. Pembimbingan khusus hanya diberikan jika terpidana mati membutuhkan berdasarkan kebutuhan, yang dilakukan oleh Psikolog LAPAS dan Kepala Seksi Pembinaan Narapidana.

${ }^{56}$ Wawancara dengan Bp. Joko, Kepala LAPAS Lowokwaru, dan Mantan Kepala RUTAN Medaeng, di Ruang Kerja, tanggal 21 September 2011.

${ }^{57}$ Kesehatan Rio Martil Maut Dicek 10 Menit Sekali, http://news.okezone.com

${ }^{58}$ Wawancara dengan Bp. Mulyadi, Kepala Bidang Seksi Pembinaan Narapidana LAPAS Lowokwaru, di Ruang Kerja, tanggal 16 September 2011.
Arah pembimbingan terpidana mati lebih difokuskan agar terpidana mati dapat hidup berdampingan secara baik dalam LAPAS, bertingkah laku baik sesuai dengan tata tertib LAPAS, dan lebih mendekatkan diri pada Tuhan. Ternyata pemberian "nasihat" kepada terpidana mati" dapat juga disampaikan oleh narapidana mati yang kesehatan mentalnya sudah matang.

Selama ini, pembimbingan kesehatan mental terpidana mati dilakukan oleh petugas pemasyarakatan (seksi bimbingan pemasyarakatan) di-bareng-kan melalui pendidikan agama, pendidikan kesadaran hukum, sehingga tidak jelas perbedaannnya antara pembimbimbangan mental dan pembimbingan keagamaan. Hal ini dilakukan karena tidak ada pedoman yang operasional untuk pembimbingan kesehatan mental terpidana mati selama menunggu dan menjelang eksekusi.

Berdasarkan hasil analisis fenomenologis, diketahui bahwa terpidana mati memaknai pidana mati (sebagai fenomena) secara bervariasi, tetapi umumnya mereka tidak ingin mengemukakan kembali atau mengingat kembali tindak pidana yang dilakukan. Mereka lebih suka membicarakan persoalan lain yang lebih bermanfaat, misalnya cara-cara lebih mendekatkan diri pada Tuhan, dan cara malakukan kegiatan positif agar lebih bermanfaat bagi sesamanya. "Saya disini sedang menjalankan tugas negara". ${ }^{59}$ "Saya sebagai warganegara harus menjalankan tugas secara bertanggungjawab. Teman-teman saya harus saya dorong agar menjadi warga negara yang bertanggungjawab. Kepercayaan orang lain harus saya jaga." Secara individual dapat diperhatikan dalam uraian berikut.

a. Suud Rusli mengemukakan bahwa dia menjalani masa-masa menunggu eksekusi, dengan memaknai sebagaimana dia sedang "menjalankan tugas negara." Hal ini dapat dipahami karena dia adalah

\footnotetext{
${ }^{59}$ Wawancara dengan Suud Rusli, di Ruangan Kepala Seksi Pembinaan Narapidana, dan di Lapangan Olah Raga LAPAS Porong.
} 
bekasmarinir.Karenasedangmenjalankan tugas, maka selama dia dalam LAPAS akan selalu menjalankan perintah petugas sebaik mungkin, dan menjalankan perintah Tuhan sebaik mungkin, serta membantu sesama agar hidupnya lebih bermanfaat. Jika dia menjalankan tugas negara secarabaik dan bertanggungjawab, maka dia meyakini akan mendapatkan penghargaan dari pemberi tugas, dan akhirnya akan bahagia. Tugas yang diberikan oleh Petugas LAPAS untuk ikut membina kesehatan mental temanteman narapidana, termasuk terpidana mati lain, adalah bentuk kepercayaan dan penghargaan yang harus dijalankan secara bertanggungjawab.

b. Markus mengemukakan bahwa "di LAPAS adalah tempat untuk mengabdi kepada sesama manusia." ${ }^{60} \mathrm{Hal}$ ini dapat dipahami karena dia pernah menjadi perawat kesehatan di salah satu Rumah Sakit Swasta di Surabaya, yang khusus mempelajari tentang anastesi. Pada saat bekerja dahulu, dia berkali-kali mengikuti pendidikan dan pelatihan. Kemampuan tersebut harus selalu diamalkan, termasuk di LAPAS. Karena itu, Markus sering membantu petugas kesehatan LAPAS untuk memberikan pelayanan bidang kesehatan kepada sesama narapidana. ${ }^{61}$

Namun demikian, ada terpidana mati lainnya di LAPAS Porong yang belum bermental sehat (sebagaimana Suud dan Markus), misalnya terpidana mati yang pernah menghasut narapidana lain untuk melawan petugas. Namun, karena beberapa pertimbangan terpidana mati tersebut dipindah ke Nusakambangan. Terpidana mati banyak yang mengalami kesusahan yang berlebihan. ${ }^{62}$ Secara umum, mungkin suatu hal yang wajar jika terpidana mati mengalami stress selama menunggu dan menjelang ek-

\footnotetext{
${ }^{60}$ Wawancara dengan Markus Pata Sambo, di Ruang Kepala Seksi Pembinaan narapidana.

${ }^{61}$ Wawancara dengan Bp. Eddy Turyono, Kepala Bidang Pembinaan Narapidana, LAPAS Porong, di Ruang Kerja, tanggal 14 Agustus 2011

${ }^{62} \mathrm{Ibid}$, tanggal 13 Agustus 2011
}

sekusi mati. Jangankan terpidana mati, terpidana lainpun juga mengalami stress. ${ }^{63}$ Tingkat stress yang tinggi pada terpidana mati juga terjadi di luar Indonesia. Ratu Marie Antoinette dari Scotlandia ketika menghadapi eksekusi dengan guillotine, tiba-tiba rambutnya langsung memutih. Padahal tadinya terpidana tersebut nampak baik dan wajar. Hal itu menggambarkan betapa hebatnya stress yang dia pendam sebelumnya. Banyak narapidana hukuman mati yang masa eksekusinya ditunda, tidak bisa menahan ketakutannya. Suatu saat, mereka tiba-tiba berteriak-teriak histeris di dalam selnya. ${ }^{64}$

Berdasarkan gambaran tersebut, dapat dipahami bahwa ada 3 pemahaman utama dalam hasilpenelitian darisisifenomenologis, yaitu sebagai berikut.

1. Belum adanya pedoman sebagai suatu hal yang dapat digunakan untuk mengembangkan pola pembinaan terpidana mati. Namun, karena keterbasan sumberdaya manusia dan dana, serta kemampuan pengelolaan, maka pembinaan yang dilakukan selama ini hanya didasarkan pada upaya agar terpidana mati tidak stress atau melarian diri atau melakukan tindak pidana kembali di dalam LAPAS/RUTAN. Karena itu, langkah-langkah pembinaannya disamakan dengan pembinaan mental dan kerohanian narapidana atau tahanan lain. Akibatnya, ada beberapa terpidana mati yang mengalami gangguan kesehatan mental.

2. Belum adanya pedoman dimaknai sebagai hal yang biasa oleh pihak LAPAS karena keterbatasan kemampuan pemerintah dalam mengelola LAPAS yang jumlahnya cukup banyak dan bervariasi. Selain itu, dapat pula dimaknai bhwa kesehatan mental terpidana mati dianggap belum

\footnotetext{
${ }^{63}$ Wawancara dengan Bp. Bambang, Kepala Kesatuan Pengamanan Lembaga Pemasyarakatan (KPLP) LAPAS Porong, di Lapangan Olah Raga, tanggal 14 Agustus 2011.

${ }^{64}$ Kehidupan \& Stress, Emotional Freedom Techniques (EFT), http://eft.co.id, diakses tanggal 22 September
} 2011 
penting untuk dipelihara, dibandingkan dengan kesehatan fisik.

3. Terpidana mati sebagai orang yang perlu diajak dialog, bahkan sangat potensial, sehingga dapat dijadikan sarana untuk meringankan terpidana

Berdasarkan semua hasil penelitian di lokasi penelitian dan analisis data di atas, dapat dipahami bahwa pembinaan terpidana mati belum dilakukan secara terencana, terus-menerus dan berkesinambungan, bahkan hanya disamaratakan sehingga kesehatan mental terpidana mati masih labil dan berpeluang melakukan tindakan pelanggaran hukum. Langkah pembimbingan tersebut tidak sesuai dengan konsep individualissi pembinaan dalam hukum pidana, yaitu melakukan pembinaan sesuai dengan kebutuhan dan kondisi terpidana. Dalam perspektif psikologis, pembinaan yang dilakukan tidak terprogram juga tidak relevan dengan teori dasar andragogi yang lebih mengutamakan pendidikan berdasar kebutuhan. Konseling yang dilakukan secara pasif (menunggu munculnya gejala ketidaksehatan mental), dan model konseling yang tidak terarah juga tidak sesuai dengan prinsip dasar konseling yang mengutamakan dialog terprogram. Pembimbingan kesehatan mental yang tidak dilakukan berdasarkan hasil pemeriksaan psikologis yang sahih, juga tidak akan berjalan dengan baik karena tidak diketahui unsur-unsur fundamental dalam kepribadian setiap terpidana mati mana yang akan dimodifikasi, bagaimana cara modifikasinya.

Bermula dari ketiadaan pedoman dan keterbatasankemampuan sumberdaya manusia dan sumber dana tersebut, maka langkah strategis yang perlu dilakukan LAPAS adalah melakukan Tes Kesehatan Mental terhadap narapidana. Tes tersebut dilakukan dengan cara menggunakan standarisasi Tes Kesehatan mental Indonesia. Tes Kesehatan Mental Indonesia (TKMI) dirancang untuk memenuhi kebutuhan Indonesia dengan merujuk pada konsep dan paradigma baru dalam MMPI-2RF, mempertahankan beberapa kelebihan dari MMPI-2 dan MMPI-1 berdasarkan pengalaman empirik sejak tahun 1982 dipakai di Indonesia. Sehingga tampilan dari TKMI dengan 350 item. Tes Kesehatan Mental Terpidana mati akan bermanfaat sebagai berikut: (1) Mengetahui struktur dasar kepribadian (Personality Traits) dengan variabel Openness, Conscientiousness, Extraversion, Agreeableness, Neuroticism; (2) Mengetahui indeks kapasitas mental kepribadian(potensikinerja, kemampuanadaptasi, kendala psikologis, perilaku berisiko, dan integritas moral).; (3) Menyaring gejala klinis gangguan jiwa (depresi, anxietas, psikotik); (4) Mengetahui indeks kepribadian dasar peserta tes (keterbukaan terhadap pikiran baru, kemampuan mendengarkan orang lain, keterbukaan terhadap orang lain, kebersamaan, dan hubungan-hubungan interpersonal, keterbukaan terhadap kesepakatan sehingga tidak timbul konflik, penerimaan terhadap tekanan); (4) Menyaring perilaku yang berisiko merugikan (penyalahgunaan zat, agresivitas).

Hasil tes kesehatan mental tersebut ditindaklanjuti dengan pemeriksaan peikiatrik, melalui wawancara psikiatrik, riwayat psikiatrik, dan pemeriksaan status mental. Wawancara klinis adalah hubungan tatap muka antara pasien dengan ahli klinis agar ahli kinis memunyai peluang awal mempelajari lebih banyak tentang masalah dan sejarah pasien (terpidana mati). Informasi awa dapatdiperoleh dari putusan pengadilan, atau catatan-catatan dari LAPAS atau RUTAN lain (jika terpidana mati merupakan terpidana pindahan dari tempat lain).

Berdasarkan hasil wawancara ini, ahli klinis akan memperoleh kesan diagnostik awal sehingga dapat memberikan penilaian secara tepat. Hal ini dilakukan dengan cara, ahli klinis menyusun pertanyaan baku untuk mengumpulkan informasi tentang keluhankeluhan atau masalah-msalah, keadaan mental, lingkungan hidup, dan sejarah psikososial atau perkembangan terpidana mati. Berdasarkan hasil tes, wawancara, dan 
observasi terhadap terpidana mati dapat bermanfaat untuk, (1) Penempatan terpidana mati dalam blok atau sel; (2) Pembimbingan kesehatan mental agar selalu bertingkah laku baik; (3) Berpikir positif; (4) Menghindari kecemasan, mencegah depresi bahkan gila, dan menyiapkan terpidana untuk di-eksekusi.

Berpijakpadakesimpulantersebut,LAPAS perlu melakukan langkah-langkah berikut: (1)Dalam masa pemeriksaankesehatan (yaitu pada saat pemeriksaan oleh dokter) perlu diadakan tes kesehatan mental oleh dokter atau psikolog; (2) Dalam masa admisi atau orientasi, perlu diadakan wawancara klinis dan observasi; (3) Berdasarkan hasil analisis terhadap tes, wawancara dan observasi, terpidana mati ditempatkan pada blok atau sel yang sesuai dengan kepribadiannya; dan (4) Berdasarkan hasil analisis terhadap tes, wawancara dan observasi disusun rencana pembimbingan kesehatan mental terpidana mati secara massal maupun individual.

Berdasarkan hasil penelitian dan analisis yuridis serta psikologis, dapat direkomendasikan tentang langkah-langkah pembimbingan kesehatan mental di LAPAS/ RUTAN sebagai berikut: (1) Merumuskan Pedoman Pembinaan Mental terpidana Mati selama Menunggu dan Menjelang Eksekusi Mati, beserta standar dan modul pelaksanaanya; (2) Membangun komitmen pihak-pihak terkait; (3) Membangun kapasitas sumber daya di dalam dan luar LAPAS; (4) Membangun jejaring pelaksanaan Pembimbingan kesehatan mental di LAPAS dan RUTAN; (5) Penemuan kasus Gangguan Mental; (6) Penatalaksanaan kasus Gangguan Kesehatan Mental; (7) Mengembangkan sistem informasi untuk surveilans; (8) Kegiatan monitoring dan evaluasi; (9) Memperkuat promosi kesehatan di lingkungan LAPAS dan RUTAN; dan (10) Mobilisasi pendanaan.

\section{Kesimpulan}

Berdasarkan hasil penelitian dan pembahasan, simpulan yang diperoleh adalah sebagai berikut: (1) Pelaksanaannya tidak didasarkan pada pedoman khusus yang kriterianya jelas dan rinci, namun hanya didasarkan pada "pemaknaan masing-masing Kepala Seksi Pembinaan Narapidana mati terhadap pembimbingan mental," dan prediksi kebutuhan terpidana mati selama menunggu eksekusi. Pembimbingan tersebut terintegrasi dengan pembimbingan mental dan kerohanian (kegiatan keagamaan). Karena itu, hasilnya belum optimal. Tujuan utamanya adalah agar terpidana mati tdak melakukan perbuatan yang melanggar hukum selama menunggu eksekusi, dan siap menjalani ekseskusi mati. (2) Pembimbingan kesehatan mental dilakukan secara massal dan individual, dengan melibatkan pembimbing keagamaan dari dalam dan luar LAPAS. Khusus pembimbingan yang bersifat individual melalui konseling pribadi hanya dilakukan jika psikolog mengangap bahwa terpidana mati membutuhkan pembimbingan. Sesama narapidana mati yang mentalnya sehat juga dapat melakukan bimbingan mental kepada terpidana mati lainnya yang membutuhkan. (3) Pemeriksaan psikologis (misalnya melalui Tes Kesehatan Mental Indonesia, wawancara klinis dan observasi) belum digunakan sebagai dasar pembimbingan mental terpidana mati, begitu pula pengukuran tentang sehat atau tidaknya mental terpidana mati selama menunggu dan menjelang eksekusi mati.

Untuk melakukan pembimbingan kesehatan mental diperlukan sebuah model pedoman pembimbingan terpidana, Standard Operating Procedure (SOP), dan modul yang sudah teruji secara yuridis dan psikologis. Pedoman tersebut dituangkan dalam Bentuk Peraturan Menteri Hukum dan HAM Republik Indonesia. Dalam pedoman tersebut harus ada kewajiban LAPAS/RUTAN untuk melakukan Tes Kesehatan Mental terhadap terpidana mati, yaitu Tes Kesehatan Mental Indonesia (TKMI) Edisi Dewasa dan Remaja (2008). Berdasarkan hasil tes, wawancara, dan observasi terhadap terpidana mati dapat bermanfaat untuk, (a) Penempatan 
terpidana mati dalam blok atau sel; (b) Pembimbingan kesehatan mental agar selalu bertingkah laku baik; (c) Berpikir positif; (d)

\section{DAFTAR PUSTAKA}

Arief, Barda Nawawi. Kebijakan Legislatif: dalam Penanggulangan Kejahatan dengan Hukum Pidana, Semarang: Badan Penerbitan Universitas Diponegoro, 1994

Astuti, Made Sadhi. Pemidanaan Terhadap Anak Sebagai Pelaku Tindak Pidana. Malang: IKIP Malang. 1997

Chazawi Adami. Pelajaran Hukum Pidana (Bagian I). Malang: Biro Konsultasi dan Bantuan Hukum Fakultas Hukum Universitas Brawijaya, 2001

Daradjat, Zakiah. Kesehatan Mental. Jakarta: Gunung Agung, 1985

Hamzah, Andi dan Siti Rahayu. Suatu Tinjauan Ringkas Sistem Pemidanaan di Indonesia, Jakarta: Akademi Presindo, 1984

Hartono, Sunaryati. Penelitian Hukum Menjelang Abad XXI. Bandung: Alumni, 1984

Kartono, Kartini. Gangguan-Gangguan Psikis. Bandung: Sinar Baru, 1989

Koenjtaraningrat. Metode Penelitian Sosial. Jakarta: Rajawali, 1981

Knowles, Malcolm. The Modern Practice of Adult Education, Andragogy Versus Pedagogy. New York: Assosiation Press, 1977

Purnomo, Bambang. Kapita Selekta Hukum Pidana. Yogyakarta: Liberty, 1984

Notosoedirjo, Moeljono dan Latipun. Kesehatan Mental: Konsep dan Penerapan, Malang: UMM Press, 2000

Ruba'i, Masruchin. Pidana dan Pemidanaan. Malang: IKIP Malang, 1994

Sahetapy, J.E. Sahetapy. Suatu Studi Khusus Mengenai Ancaman Pidana Mati terhadap Pembunuhan Berencana. Jakarta: CV Rajawali, 1982
Menghindari kecemasan, mencegah depresi bahkan kegilaan, dan menyiapkan terpidana untuk di-eksekusi mati.

Soekanto, Soerjono dan Pudji Santoso. Kamus Kriminologi.\Jakarta: Rajawali, 1988

Soekanto, Soerjono dan Sri Mamudji. Penelitian Hukum Normatif: Suatu Tinjauan Singkat. Jakarta: Rajawali Press, 1995

Sudjana, H.D. Strategi Pembelajaran Dalam Pendidikan Luar Sekolah. Bandung: Falah Production, 2000.

Widodo. Kapita Selekta Hukum Pidana. Jakarta: Kertagama Publishing, 2007

Peraturan Perundang-undangan

Undang-Undang Republik Indonesia No. 23 Tahun 1992 tentang Kesehatan

Undang-Undang Republik Indonesia No. 12 Tahun 1995 tentang Pemasyarakatan

Peraturan Pemerintah No. 31 Tahun 1999 tentang Pembinaan dan Pembimbingan Warga Binaan Pemasyarakatan

Surat Edaran Mahkamah Agung Republik Indonesia (SEMA) No. 1 Tahun 2000 tentang Pemidanaan

\section{Hasil Penelitian}

Aritonang, Sahat F. 2005. Sistem Pemasyarakatan dan Pola Pembinaan Mental Narapidana Kriminal dalam Lembaga Pemasyarakatan (Studi Kasus Lembaga Pemasyarakatan Cipinang), Tesis. Universitas Indonesia.

Mulyasa.2005.PengembanganModel Andragogi Bagi Pembinaan Narapidana Perempuan di Lembaga Pemasyarakatan (Studi Terfokus pada Pendidikan Keagamaan (Islam) di Lembaga Pemasyarakatan Kelas IIA Bandung), Tesis, Program Pascasarjana Universitas Pendidikan Indonesia (UPI). Bandung.

Nugrahini, Ethika. 2007. Strategi Koping Menghadapi Pidana Mati pada Terpidana Mati, Universitas Muhammadiyah 
48 I de Jure, Jurnal Syariah dan Hukum, Volume 4 Nomor 1, Juli 2012, hlm. 34-48

Surakarta.

Simanjuntak, Wilson. 2003. Upaya mengurangi stigma masyarakat pada Narapidana. Tesis. Universitas Indonesia.

\section{Koran}

Harian Singgalang. LP Muara Bobol, Tiga Terpidana Mati Kabur. 18 Oktober 2007

Harian Bhirawa. Penghuni LAPAS Porong diberi Pembinaan Kerohanian. Selasa 11 Mei 2011

Radar Semarang. Terpidana Mati WN Nigeria Diduga Dalangi Kerusuhan. 24 Juni 2008

Radar Semarang. 52 Terpidana Mati Tunggu Eksekusi. 2 September 2008

\section{Website}

www. surabaya.detik.com. Napi Risiko Tinggi Diberi Pelatihan Kendalikan Emosi. 10 Mei 2010.

www. Metrotvnews.com. Ribuan Napi Lapas Porong Bertobat, Nusantara. Rabu, 11 Mei 2011

www.seputar-indonesia. com. Kejagung Tunggu Fatwa MA. diakses tanggal 21 Agustus 2010.

www.kapanlagi.com. 52 Napi Tunggu Eksekusi Mati. diakses tanggal 21 Agustus 2010.

www. eft.co.id, Kehidupan \& Stress, Emotional Freedom Techniques (EFT). diakses tanggal 21 Agustus 2010. www. hukum online. RUU KUHP Masih Berlakukan Hukuman Mati. diakses tanggal 25 Agustus 2010.

www. news.okezone.com. Kesehatan Rio Martil Maut Dicek 10 Menit Sekali.

diakses tanggal 21 September 2011.

\section{Hasil Wawancara}

Wawancara dengan Bp. Eddy Turyono, Kepala Bidang Pembinaan Narapidana, LAPAS Porong, di Ruang Kerja, tanggal 12 Agustus 2011.

Wawancara dengan Bp. Bambang, Kepala Kesatuan Pengamanan Lembaga Pemasyarakatan (KPLP) LAPAS Porong, di Lapangan Olah Raga, tanggal 14 Agustus 2011.

Wawancara dengan Bp. Eddy Turyono, Kepala Bidang Pembinaan Narapidana, LAPASPorong, di Ruang Kerja, tanggal 14 Agustus 2011.

Wawancara dengan Bp. Mulyadi, Kepala Bidang Seksi Pembinaan Narapidana LAPAS Lowokwaru, di Ruang Kerja, tanggal 16 September 2011.

Wawancara dengan Udin, Pegawai LAPAS Lowokwaru Malang. Tanggal 16 September 2011.

Wawancara dengan Bp. Joko, Kepala LAPAS Lowokwaru, dan Mantan Kepala RUTAN Medaeng, di Ruang Kerja, tanggal 21 September 2011. 